\title{
Pengaruh Brand Equity Dan Kualitas Produk Terhadap Keputusan Pembelian Laptop Merek Asus di Kota Tabanan
}

\author{
I Made Sukma Diarta*1, I Nengah Suarmanayasa ${ }^{2}$ \\ 1,2,3 Program Studi Manajemen \\ Universitas Pendidikan Ganesha \\ Singaraja, Indonesia
}

Riwayat Artikel
Tanggal diajukan:
26 Februari 2021
Tanggal diterima :
22 November 2021
Tanggal
dipublikasikan:
15 Desember 2021

Pengutipan:

Diarta, I. M. S. \&

Surmayasa, I. N.

(2021). Pengaruh

Brand Equity dan

Kualitas Produk

Terhadap

Keputusan

Pembelian Laptop

Merek Asus di Kota

Tabanan. Jurnal

Pendidikan

Ekonomi Undiksha,

13 (2), 268-275

http://dx.doi.org/10.

23887/iipe.v13i2.32

703

\section{e-mail: imadesukmadiarta08@undiksha.ac.id ${ }^{* 1}$, nengah.suarmanayasa@undiksha.ac.id ${ }^{2}$}

\begin{abstract}
Abstrak
Riset ini berarti memeriksa dampak nilai brand equity dan kualitas produk secara bersamaan dan tidak lengkap pada keputusan pembelian. Desain penelitian yang digunakan adalah kuantitatif kausal. Subjek penelitian ini adalah konsumen laptop merek Asus di kota Tabanan dan objek penelitiannya adalah brand equity, kualitas produk dan keputusan pembelian. Data dikumpulkan dengan metode kuesioner dengan analisis regresi linier berganda. Hasil penelitian menunjukkan bahwa (1) brand equity dan kualitas produk berpengaruh signifikan terhadap keputusan pembelian sebesar $69,2 \%$, (2) brand equity berpengaruh positif dan signifikan terhadap keputusan pembelian sebesar $31,3 \%$, (3) kualitas produk berpengaruh positif dan signifikan terhadap keputusan pembelian sebesar $31,5 \%$.
\end{abstract}

Kata kunci: Brand Equity; Kualitas Produk; Keputusan Pembelian.

\section{Abstract}

This study aims to examine the effect of brand equity and product quality simultaneously and partially on purchasing decisions. The research design used is quantitative causal. The subject of this research is the consumer of Asus laptop in Tabanan city and the object of research is brand equity, product quality and purchasing decision. Data were collected using a questionnaire method with multiple linear regression analysis. The results showed that (1) brand equity and product quality had a significant effect on purchasing decisions by $69.2 \%$, (2) brand equity had a positive and significant effect on purchasing decisions by $31.3 \%$, (3) product quality had a positive and significant effect. to the purchasing decision of $31.5 \%$.

Kata kunci: Brand Equity; Product Quality; Purchasing Decisions. 


\section{PENDAHULUAN}

Komputer pangku adalah item yang paling sering dipakai secara konsisten. Komputer pangku menguasai segmen pembantu secara eksplisit dimaksudkan untuk memenuhi ide nyaman dari PC serbaguna. Properti utama yang dikuasai oleh elemen pembentuk komputer pangku adalah berukuran mikro, produktif dalam pemaanfaatan energi, dan mahir. Kesempatan market yang tinggi dimanfaatkan oleh industri komputer pangku untuk memajukan paket produk dan karakteristik barang untuk menarik pembeli. Asus adalah label laptop pangku yang di senangi pembeli di Indonesia. Ramainya pembeli telah memutuskan keputusan mereka untuk membeli komputer pangku Asus (Irawati \& Kurniawan, 2017).

Laptop merek Asus banyak diminati masyarakat di kota Tabanan dari data yang di peroleh dari salah satu toko laptop di Tabanan yaitu toko Bali Nirmala Komputer menujukan bahwa penjualan laptop Asus merupakan yang tertinggi dari dua merek lain yaitu HP dan Acer (Lampiran 01). penjualan laptop Asus dan HP pada 3 bulan terakhir di tahun 2020 mengalami fluktuasi, sedangkan penjualan laptop Acer terus mengalami kenaikan. Pejualan laptop di Toko Bali Nirmala Komputer pada bulan juni ke juli mengalami kenaikan, dimana laptop Asus kenaikannya paling tinggi yaitu $250 \%$ sedangkan laptop HP hanya $17 \%$ dan laptop Acer hanya 25\%. Peningkatan tersebut terjadi karena peningkatan keputusan pembelian pada laptop Asus.

Menurut (Agustini, 2017) pilihan adalah keputusan dari setidaknya dua keputusan elektif. Pilihan pembelian pembelanja sebagai aspek primer dalam menentukan keberadaan suatu organisasi. Sebuah organisasi bisa tetap ada jika peningkatan pembeli dalam memilih untuk membeli dari pasar memperoleh reaksi bagus dari pasar yang sebenarnya. Untuk mengetahui seberapa besar tingkat keputusan pembelian Laptop Asus di kota Tabanan maka sebelumnya telah dilakukan penyebaran kuesioner awal terhadap 10 responden. Menurut Swastha dan Irawan (dalam Widyasari \& Fifilia, 2009:161) terdapat tujuh indikator dalam keputusan pembelian diantaranya pilihan tentang karakteristik barang $\left(\mathrm{Y}_{1}\right)$, pilihan tentang strutur barang $\left(\mathrm{Y}_{2}\right)$, pilihan tentang merek $\left(Y_{3}\right)$, pilihan tentang penawaran $\left(Y_{4}\right)$, pilihan tentang jumlah barang $\left(Y_{5}\right)$, pilihan tentang kapan harus membeli $\left(Y_{6}\right)$, pilihan tentang teknik pembayaran $\left(\mathrm{Y}_{7}\right)$. Berikut hasil kuesioner awal terhadap 10 responden pada konsumen laptop Asus di kota tabanan. Hasil kuesioner yang telah disebar menunjukan tingginya keputusan pembelian laptop Asus dengan skor 294 (lampiran 04). Indikator keputusan tentang waktu pembelian menciptakan efek terbesar pada pilihan pembelian. Menurut Schiffman \& Kanuk, 2010 pilihan pembelaja dalam menentukan pilihan pembelian disebabkan oleh banyak aspek diantaranya equitas merek dan mutu barang.

Menurut kotler dan keller (dalam Nujulia, 2015:39) Equitas Merek merupakan kualitas yang di persembahkan oleh barang atau pelayanan. Hal tersebut dapat dilihat dari cara pembeli berpandangan, merasa dan berlaku tentang citra, nilai, bagian dari market dan daya laba miliki organisasi. Menurut Pradipta, dkk 2016 merek amat menarik dalam pilihan pembelian, menjadi karakter organisasi, dan menjadi deferensiasi yang dimulai dengan satu item kemudian ke item berikutnya. Dalam kuisioner equitas merek tersebut terdapat tujuh indkator: leadership $\left(\mathrm{x}_{1.1}\right)$, stability $\left(\mathrm{x}_{1.2}\right)$, market $\left(\mathrm{x}_{1.3}\right)$, Internationality $\left(\mathrm{x}_{1.4}\right)$, Trend $\left(\mathrm{x}_{1.5}\right)$, Support $\left(\mathrm{x}_{1.6}\right)$, Protection $\left(\mathrm{x}_{1.7}\right)$. Hasil kuesioner yang telah disebar menunjukan variabel brand equity laptop Asus pada konsumen di kota Tabanan tergolong dalam kategori tinggi dengan skor 294 (Lampiran 04). Indikator Trend memberikan dampak terbesar pada pilihan pembelian. Hal ini menunjukan tingginya keputusan pembelian laptop Asus di kota Tabanan dikarenakan Produk yang diluncurkan laptop Asus sesuai dengan trend sehingga menarik perhatian konsumen di kota Tabanan untuk melakukan keputusan pembelian, jadi jika produk laptop Asus mengikuti trend akan memberikan nilai tambah bagi konsumen yang dapat meningkatkan equitas merek sehingga dapat mendorong adanya keputusan pembelian. 
Menurut Kotler (Amrullah \& Zainurossalamia, 2016:102) kualitas barang merupakan atribut suatu barang atau administrasi yang mempengaruhi kapasitas untuk memenuhi keperluan yang dinyatakan atau disarankan, pembuat dapat membeikan mutu barang atau administrasi yang dipersembahkan dapat memenuhi atau melampaui asumsi pembeli. Menurut Nabhan dan Kresnaini, (dalam Pujiwidodo, 2016:5) pembeli dalam menentukan pilihan pembelian secara konsisten memikirkan halhal yang didefinisikan dengan sifat barang yang hendak dibeli. Dalam kuisioner mutu barang tersebut terdapat lima indikator: kinerja $\left(x_{2.1}\right), \quad$ kehandalan $\left(x_{2.2}\right)$, keistimewaan $\left(\mathrm{x}_{2.3}\right)$, kemampuan pelayanan $\left(\mathrm{x}_{2.4}\right)$, daya tahan $\left(\mathrm{x}_{2.5}\right)$. Hasil kuesioner yang telah disebar menunjukan variabel kualitas produk yang dalam tergolong katagori tinggi dengan skor 214 (Lampiran 04). Indikator keistimewaan memberiakan pengaruh paling besar atas pilihan beli komputer pangku Asus di kota Tabanan. Hal ini menunjukan tingginya keputusan pembelian laptop Asus di kota Tabanan dikarenakan keistimewaan atau fitur yang di tawarkan produk Laptop Asus sangat baik di bandingkan produk laptop merek lain. Keistimewaan atau fitur yang bagus yang dimiliki sebuah produk akan mencerminkan kualitas produk tersebut sehingga akan mempengaruhi pilihan pembelian pembelian.

Motivasi di balik riset ini adalah untuk menguji pengaruh berikut ini : (1) hubungan brand equity serta mutu barang dalam membeli pilihan laptop Asus di kota Tabanan, (2) Dampak brand equity dalam membeli pilihan produk laptop Asus di kota Tabanan, (3) Dampak kualitas produk dalam membeli pilihan produk laptop Asus di kota Tabanan.

Pilihan pembelian di akibatkan oleh banyak variabel misalnya: nilai merek, mutu barang dan komponen yang berbeda (Menurut Schiffman \& Kanuk, 2010). Brand equity bisa mempengaruhi kepercayaan pembeli dalam menentukan pilihan pembelian bedasarkan pengetahuan terdahulu dalam pemakaian, hubungan dengan atribut merek yang berbeda suharyani (dalam Putri \& Suasana,
2017:473). Mutu barang yang dijual perlu cocok dengan keperluan pembeli untuk mendapatkan arah organisasi dalam memperluas kapasitas bisnisnya. Karenanya barang menjadi hal penting dalam pemasaran, pencapaian organisasi bisa dilihat dari reaksi yang ditampilkan oleh pelanggan. Mutu barang bisa menjadi aspek penting buat pembeli saat menentukan pilihan pembelian.

$\mathrm{H}_{1}$ : Ada dampak equitas merek dan kualitas produk pada keputusan pembelian laptop Asus di kota Tabanan.

Merek amat kuat efeknya dalam pilihan pembelian, seperti identitas karakter organisasi, dan hal yang membedakan yang dimulai dengan satu item kemudian ke item berikutnya. Merek adalah lambang yang bisa membentuk kesan pembeli pada barang tertentu. Citra merek bisa menjadi latar belakang pembeli untuk melaksanakan pembelian atas beragam evaluasinya. Jika tidak ada brand, pembeli mesti menyurvie berbagai barang yang belum mempunyai brand ketikapembeli mau melaksanakan pembelian. Dengan equitas merek menjadikan suatu brand menjadi tangguh sehingga bisa memudahkan memikat perhatian konsumen terpendam, hingga bisa memberikan kesenangan dan kepercayaan bahwa pembeli sudah terpenuhi karena barang itu menjadikan pembeli lebih sitia dan hendak melaksanakan pembelian berulang (Pradipta et al., 2016).

$\mathrm{H}_{2}$ : Ada dampak equitas merek terhadap keputusan pembelian laptop Asus di kota Tabanan.

Pembeli di dalam melangsungkan keputusan pembelian tetap memikirkan sesuatu yang berkaitan pada mutu oleh barang yang bakal dibeli. Ketika pembeli bakal memilih satu keputusan pembelian, faktor barang menjadi estimasi yang pertama, akibatnya barang ialah intensi terbaik bagi pelanggan demi mencukupi keperluannya. Pelanggan merasakan kesesuaian terhadap barang sehingga barang itu bisa mencukupi keperluannya, hingga pelanggan bisa memutuskan mengkonsumsi barang tersebut Nabhan dan Kresnaini (dalam Pujiwidodo 2016:5). Pelanggan bisa menjadi puas jika 
p-ISSN : 2599-1418

e-ISSN : 2599-1426

pertimbangan konsumen memperlihatkan bahwa barang yang dikonsumsi memiliki kualitas. barang yang mempunyai mutu tinggi dan dipercaya, hingga barang bisa selalu diingat dalam pikiran pelanggan, akibatnya pelanggan mau mengeluarkan biaya membeli barang bermutu tinggi (Kasanti, dkk 2019).

H3 : Ada pengaruh kualitas produk terhadap keputusan pembelian laptop Asus dikota Tabanan.

\section{METODE}

Riset ini memakai desain penelitian kuantitatf. Sugiyono (dalam Bella and Bachri 2020) mengartikan desain kuantitatif sebagai teknik riset bergantung pada cara berfikir positif, dipakai memeriksa pada populasi atau tes tertentu, menghimpunkan informasi memakai instrumen riset, kajian informasi bersifat kuantitatif/faktual, dengan intensi memvisualkan dan menguji teori-teori yang ditentukan sebelumnya. Desain riset yang bermaksud untuk memastikan hubungan dan dampak oleh satu faktor pada faktor lainya, yaitu menganaslisis hubungan sebab akibat antara faktor independen $(x)$ dan faktor dependen (y).

Subjek riset ini ialah pelanggan laptop Asus di Kabupaten Tabanan serta objek risetnya ialah brand equity, mutu brang, dan keputusan pembelian laptop Asus di tabanan. Pada riset ini menggunakan sampel sebesar 100 responden. Teknik Pengumpulan penghimpunan informasi yang dipakai di riset ini yaitu teknik kuesioner. Di dalam riset ini rasio yang dipakai untuk pembuatan kuisioner adalah skala ordinal atau skala likert, menggunakan lima pilihan jawaban yakni dipakai untuk menilai prilaku, gagasan, dan tanggapan seseorang atas pertanda sosial.

Di dalam riset ini desain dan cara mengkajii informasi yang dipakai yaitu kajian regresi linier berganda. Regresi berganda digunakan memeriksa kuatnya hubungan dari faktor ekuitas merek $\left(\mathrm{x}_{1}\right)$ serta mutu barang $\left(\mathrm{x}_{2}\right)$ pada faktor keputusan pembelian (y). Sebelum data diolah ke analisis regresi berganda, sebelumnya
Jurnal Pendidikan Ekonomi Undiksha

Vol. 13 No. 2 (2021)

harus di tes dengan pengujian asumsi klasik, karena syarat untuk analisis regresi berganda adalah bebas dari asumsi-asumsi klasik.

\section{HASIL DAN PEMBAHASAN}

Berlandaskan nilai kalkulasi uji regresi linier berganda memperoleh nilai $\mathrm{F}$ sebesar $0,692 \neq 0$ serta $p$-value $0,000<$ alpha 0,05 karenanya Ho tidak diterima yang artinya terdapat pengaruh spesifik equitas merek serta mutu barang pada keputusan pembelian. Maka kesimpulannya adalah equitas merek dan mutu barang berhubungan benar dan spesifik pada keputusan pembelian laptop brand Asus dikota Tabanan.

Dari perhitungan uji t equitas merek memiliki koefisien korelasi sebesar $0,313 \neq 0$ dengan $p$-value $0,002<$ alpha 0,05 karenanya Ho tidak diterima artinya ada hubungan equitas merek pada keputusan pembelian. Maka kesimpulannya adalah equitas merek berhubungan benar dan spesifik pada pembelian komputer pangku brand Asus dikota Tabanan. Sedangkan mutu barang mempunyai koefisien korelasi dengan nilai $0,315 \neq 0$ serta $p$-value $0,001<$ alpha 0,05 sehingga Ho tidak diterima berarti terdapat hubungan mutu barang pada keputusan pembelian. Maka dapat disimpulkan bahwasannya mutu barang berhubungan benar spesifik pada pembelian laptop merek Asus di kota Tabanan.

Pada nilai koefisien determinan $\left(\mathrm{R}^{2}\right)$ didapat hasil dengan besar 0,478 (47,8\%), hasil tersebut memperlihatkan bahwasannya Keputusan pembelian terpengaruh brand equity serta mutu barang dengan nilai $47,8 \%$, sementara $52,2 \%$ terpengaruh faktor lainnya yang tidak dikaji pada riset ini. Adapun faktor lainnya yang berhubungan dengan keputusan pembelian di pengaruhi oleh atribut produk, iklan dan kelompok acuan, (Viana \& Wartini, 2016).

Struktur Hubungan Pengaruh Brand Equity dan Kualitas Produk terhadap Keputusan Pembelian seperti nampak pada Gambar 1 (Lampiran 10). 


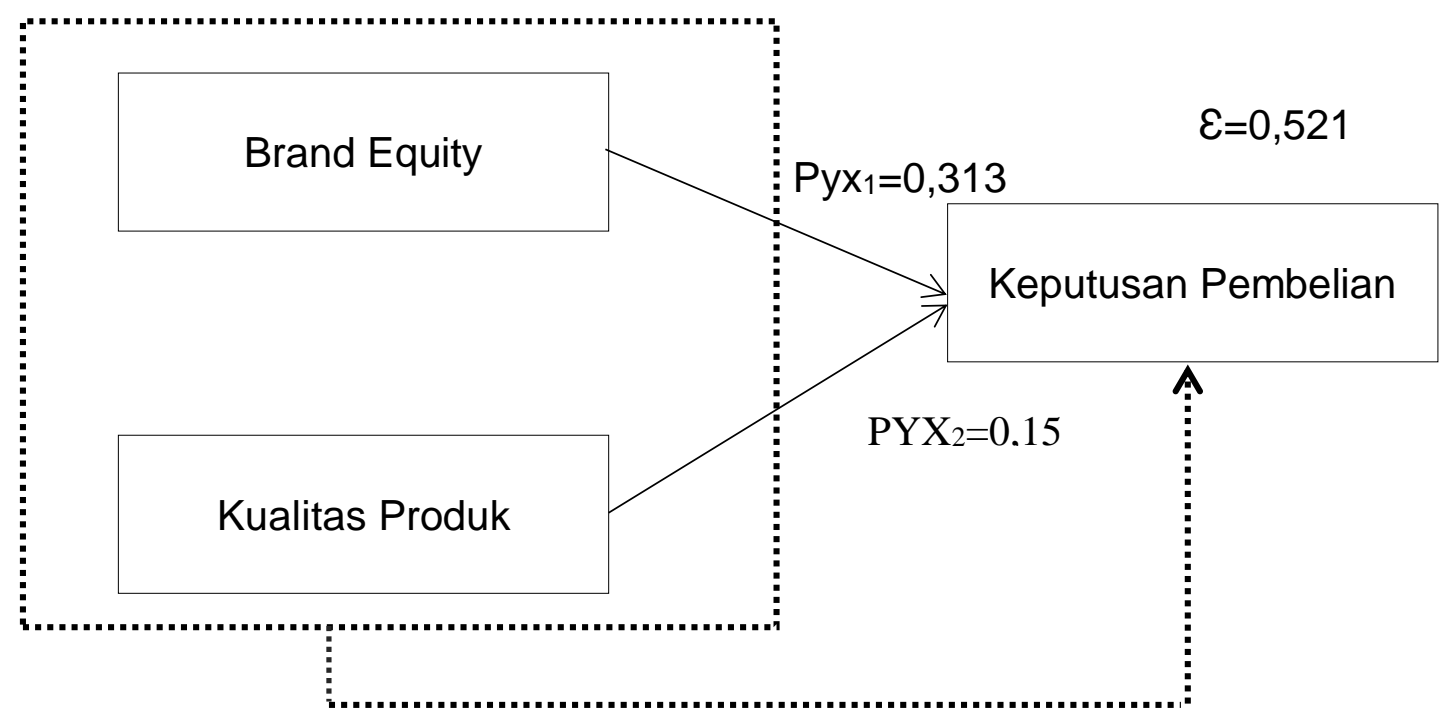

$\mathrm{PYX}_{1} \mathrm{X}_{2}=478$

Gambar 1 : Struktur Hubungan Pengaruh Brand Equity dan Kualitas Produk terhadap Keputusan Pembelian

Sehingga persamaan regresi diformulasikan sebagai berikut :

$\bar{Y}=9,500+0,347 X 1+0,473 X 2+\varepsilon$

Penjabaran dari keluaran kajian regresi lenier berganda berikut ini. (1) kostanta ( $\alpha$ ) sebesar 9,500 artinya bahwa apabila pertumbuhan brand equity $\left(\mathrm{x}_{1}\right)$ serta mutu barang $\left(\mathrm{x}_{2}\right)$, mempunyai angka sama dengan nol, kemudian keputusan pembelian (Y) sejumlah 9,500. (2) angka koefisien brand equity ( $\beta 1$ ) dengan nilai 0,347 berhubungan benar pada putusan pembelian (Y). Ini artinya bahwasannya masing-masing peningkatan brand equity satu persen maka faktor Keputusan Pembelian meningkat sejumlah 0,347, sehingga Keputusan pembelian menjadi $9,847 \%$ serta perkiraan bahwasannya faktor bebas yang lainnya tetap. (3) Nilai koefisien kualitas produk ( $\beta 2)$ sejumlah 0,473 berhubungan benar pada keputusan pembelian ( $(Y)$. Ini artinya bahwasannya masing-masing peningkatan satu persen kualitas produk lalu faktor keputusan pembelian mengalami kenaikan sejumlah 0,473 sehingga keputusan pembelian menjadi menjadi $9,973 \%$, setelah perkiraan bahwasannya faktor independen yang lainnya tetap.

Keluaran dari riset ini memperlihatkan variabel bebas yakni brand equity dan mutu barang berhubungan spesifik pada keputusan pembelian produk laptop Asus di kota Tabanan. Ini memperlihatkan bahwa faktor mutu produk dan equitas merek secara bersasamaan berperan dalam meningkatkan keputusan pembelian produk laptop Asus. Laptop Asus dalam meningkatkan penjualan harus berusaha untuk meningkatkan Brand equity yang dimiliki laptop Asus, dimana equitas merek bisa menolong konsumen untuk mengartikan, menjalankan dan menyimpan data yang berhubungan langsung terhadap barang dan brand tertentu serta berpengaruh pada keyakinan pembeli untuk melakukan pembelian produk. Dengan memberikan produk yang unggul dan sesuai dengan keinginan konsumen merek laptop Asus akan lebih terkenal dan diingat oleh masyarakat sehingga bisa menumbuhkan keputusan untuk membeli komputer pangku Asus. Komputer pangku Asus juga harus mampu meningkatkan kualitas produk yang akan di tawarkan jika ingin meningkatkan keputusan pembelian konsumen. Mutu 
p-ISSN : 2599-1418

e-ISSN : 2599-1426
Jurnal Pendidikan Ekonomi Undiksha

Vol. 13 No. 2 (2021) barang merupakan perhitungan penting pelanggan untuk membeli sebuah produk laptop. Kosumen akan mempertimbangan spesifikasi yang ada pada laptop seperti processor yang menjadi kepala yang melaksanakan metode dan pengaturan kerja dari laptop. Ketahanan baterai laptop juga menjadi pertimbangan penting karena berhubungan terhadap cangkupan serta bisa menolong untuk memastikan lamanya baterai bisa bertahan setelah pengisian penuh. Selain itu jika fitur-fitur yang ditawarkan semakin canggih akan menarik konsumen untuk membeli. Dengan memperhatikan dan meningkatkan kualitas dari produk laptop Asus sehingga akan meningkatkan keputusan pembelian. Sedangkan keluaran riset ini sejalan dengan temuan (Widiawati \& Raymond, 2020) menyatakan bahwa brand equity dan mutu barang mepunyai hubungan spesifik pada keputusan pembelian.

Keluaran dari penelitian ini memperlihatkan bahwasannya faktor bebas yaitu brand equity berhubungan signifikan pada keputusan pembelian produk laptop Asus di kota Tabanan. Ini menunjukan bahwasanya variabel brand equity berperan dalam meningkatkan keputusan pembelian produk laptop Asus. Dengan equitas merek menjadikan sebuah brand laptop Asus bisa lebih gampang dalam memikat hasrat konsumen yang terpendam, hingga bisa menumbuhkan kesenangan dan keyakinan jika pelanggan bisa terpenuhi keinginan dan kebutuhnnya oleh produk laptop Asus. Laptop Asus memberikan kelebihan tersendiri yang membuat merek dari laptop Asus melekat di benak konsumennya. Laptop Asus juga terkenal memiliki total item untuk PC gaming. Dari seri $F X$ sampai dengan $R O G$ adalah keputusan mutu terunggul untuk penggemar game dengan biaya yang masuk akal dan serius. Selain itu keunggulan dan inovasi yang terpasang laptop Asus ini sangat baik serta harga yang terjangkau. Asus memberikan garansi yang cukup panjang di bandingkan dengan produk laptop lain yakni 2 tahun. Keunggulan-keungulan seperti pemberian garansi dan biaya terjangkau dengan mutu baik serta paling diminati pelanggan sehingga membuat brand equity dari laptop
Asus meningkat dan berpengaruh terhadap peningkatan putusan pembelian. Keluaran penelitian ini berbeda terhadap penelitian dilaksanakan oleh (intan Ali, dkk 2019) hasil penelitiannya adalah brand equity tidak berhubungan signifikan pada keputusan pembelian. Tetapi keluaran riset ini mendukung temuan Setiyana and Widyasari (2019) menyatakan bahwa brand equity mempunyai hubungan spesifik pada keputusan pembelian.

Keluaran riset memperlihatkan variabel bebas yaitu mutu barang berhubungan signifikan pada keputusan pembelian produk laptop Asus di kota Tabanan. Hal ini menunjukan bahwa variabel kualitas produk berperan dalam meningkatkan keputusan pembelian produk laptop Asus. Mutu barang menjadikan variabel penting untuk pelanggan untuk melakukan keputusan pembelian laptop Asus. Laptop Asus memiliki performa dan ketahanan yang baik hal ini tak lepas dari komponen motherboardnya yang tangguh.motherboard/papan utama berguna untuk merangkaikan berbagai perangkat keras seperti prosesor, RAM, hard disk, printer, VGA, power supply, dan yang lainnya. Motherboard/papan utama bisa didefinisikan bagai fondasi dari kerangka PC, seluruh bagian PC harus berkaitan pada motherboard/papan utama, baik secara langsung ataupun imflikasinya. Selain itu laptop Asus juga bisa di andalkan untuk bermain game hal ini di karenakan Asus dilengkapi komponen kartu grafisnya atau $V G A$ yang bagus dari anti radeon dan Nvidia gerforce. VGA ini berfungsi untuk menghasilkan dan menampilkan gambar ke monitor. Kualitas-kualitas inilah yang membuat konsumen tertarik dalam melaksanakan keputusan pembelian produk laptop Asus. Riset ini berbeda pada keluaran riset dari Siti Nur Nahya, dkk (2019) dengan hasil riset mutu barang secara bersamasama tidak berhubungan spesifik pada keputusan pembelian. Sedangkan hasil penelitian ini mendukung temuan Putra, dkk (2017) menyatakan bahwasannya mutu barang berhubungan spesifik pada keputusan pembelian.

\section{SIMPULAN DAN SARAN}


p-ISSN : 2599-1418

e-ISSN : 2599-1426

Berdasarkan keluaran riset pada konsumen laptop Asus di kota Tabanan. yang sudah disajikan diatas, dapat disimpulkan hal sebagai berikut ini. (1) brand equity dan keputusan pembelian secara simultan berhubungan spesifik pada keputusan pembelian produk laptop Asus di kota Tabanan. (2) brand equity berhubungan positif spesifik pada keputusan pembelian produk laptop Asus di kota Tabanan. (3) kualitas produk berhubungan positif spesifik pada keputusan pembelian produk laptop Asus di kota Tabanan.

Dari keluaran pengkajian dengan sejumlah hasil akhir pada riset ini, beberapa gagasan yang bisa disampaikan dari keluaran riset ini supaya mempunyai keluaran terus membaik yaitu sebagai berikut. (1) Bagi Laptop Asus diharapkan mampu mempertahankan serta meningkatkan brand equity yang dimiliki produk laptop Asus dengan memberikan produk-produk yang unggul dengan begitu merek dari produk laptop Asus akan semakin dikenal oleh masyarakat luas shingga semakin banyak konsumen yang akan menjatuhkan pilihan pada produk laptop Asus. Selain itu kualitas produk juga sangat berpengaruh karena kualitas produk menjadi pertimbangan penting pelanggan untuk membeli barang laptop, lalu badasarkan hal tersebut produsen laptop Asus harus terus meningkatkan kualitas komponen-komponen pendukung sehingga konsumen akan merasa lebih puas dalam menggunakan laptop Asus sehingga bisa loyal pada produk laptop Asus dan melakukan pembelian ulang saat membutuhkan produk laptop. (2) Bagi peneliti berikutnya penelitian selanjutnya diharapkan untuk dapat membabarkan riset ini dengan memakai topik riset yang lebih luas. Selain itu pengkaji berikutnya diharapkan dalam melakukan pengujian terhadap faktor lain yang mempengaruhi keputusan pembelian. Ada beberapa faktor lain berhubungan keputusan pembelian ialah promosi, harga, kualitas pelayanan dan persepsi konsumen.

\section{DAFTAR PUSTAKA}

Agustini, N. K. D. A. (2017). Analisis FaktorFaktor yang Mempengaruhi Keputusan
Jurnal Pendidikan Ekonomi Undiksha

Vol. 13 No. 2 (2021)

Membeli di Online Shop Mahasiswa Jurusan Pendidikan Ekonomi Angkatan Tahun 2012. Jurnal Pendidikan Ekonomi Undiksha, 9(1), 127. doi: 10.23887/jjpe.v9i1.19997.

Ali, I., Irdiana, S., \& Irwanto, J. (2019). Dampak Brand Image, Brand Equity dan Brand Trust terhadap Keputusan Pembelian Laptop Asus (Studi pada Toko Komputer Lumajang Computer Centre di Kabupaten Lumajang). Progress Conference, 2(July), 406413.

Amrullah, P. S. S., \& Zainurossalamia, S. (2016). Pengaruh Kualitas Produk dan Kualitas Layanan terhadap Keputusan Pembelian Sepeda Motor Honda Fakultas Ekonomi dan Bisnis Universitas Mulawarman, Indonesia. Jurnal Ekonomi Dan Manajemen, 13(2), 99-118.

Bella, O. K., \& Bachri, B. S. (2020). Pengaruh Model Problem Based Learning terhadap Hasil Belajar pada Materi Massa Jenis Mata Pelajaran IImu Pengetahuan Alam Kelas VII di Sekolah Menengah Pertama Surabaya. Jurnal Mahasiswa Teknologi Pendidikan, 10(10).

Irawati, N., \& Kurniawan, S. (2017). Pengaruh Desain dan Kualitas Produk terhadap Kepuasan Konsumen melalui Kepuasan Pembelian Laptop Asus. Manajemen Dewantara, 1(1), 25-37.

Kasanti, N., Wijaya, A., \& Suandry. (2019). Pengaruh Harga dan Kualitas Poduk terhadap Keputusan Pembelian Produk Safety Merek Proguard pada PT AIM Safety Indonesia. Asian Journal of Innovation and Entrepreneurship, 04(1), 43-51.

Nujulia. (2015). Pengaruh Brand Equity terhadap Keputusan Pembelian Konsumen pada Produk Pasta Gigi Pepsodent (Studi Kasus pada Mahasiswa Program Studi Pendidikan Ekonomi STKIP PGRI Sumatera Barat). Jurnal Ekonomi Dan Manajemen Bisnis, 39(1), 35-37.

Pradipta, D., Hidayat, K., \& Sunarti, S. (2016). Pengaruh Brand Equity terhadap Keputusan Pembelian (Survei pada Konsumen Pembeli dan 
p-ISSN : 2599-1418

e-ISSN : 2599-1426

Pengguna Kartu Perdana Simpati Telkomsel di Lingkungan Mahasiswa Jurusan Administrasi Bisnis Angkatan 2012 \& 2013 Fakultas IImu Administrasi Universitas Brawijaya Malang). Jurnal Administrasi Bisnis $S 1$ Universitas Brawijaya, 34(1), 138-147.

Pujiwidodo, D. (2016). Pengaruh Kualitas Produk terhadap Keputusan Pembelian Layanan Internet yang Dimediasi oleh Minat Beli (Studi Kasus pada Mahasiswa Pengguna Provider Tri di Fakultas Ekonomi Universitas Negeri Yogyakarta) SKRIPSI.

Putra, D. A., Hufron, M., \& Slamet, A. R. (2017). Pengaruh Brand Image dan Kualitas Produk terhadap Keputusan Pembelian Mobil Toyota Agya di Kota Malang. Jurnal IImiah Riset Manajemen UNISMA, 06(1), 122-129.

Putri, V. D. A., \& Suasana, I. G. A. K. G. (2017). Pengaruh Elemen Ekuitas Merek terhadap Keputusan Pembelian di Gerai Starbucks Coffee (Studi pada Konsumen Domestik Starbucks Coffe di Wilayah Bali). Jurnal Manajemen Universitas Udayana, 7(1), 470. https://doi.org/10.24843/ejmunud.2018 .v7.i01.p18.

Schiffman, L. G., \& Kanuk, L. . (2010). Consumer Behaviour (10th ed). New Jersey:Pearson Prentice Hall.

Setiyana, Y., \& Widyasari, S. (2019). Pengaruh Kualitas Produk, Ekuitas Merek dan Gaya Hidup terhadap Proses Keputusan Pembelian Produk Honda Vario. Prosiding SENDI_U 2019, 8(11), 1-16.

Siti Nur Nahya, N.Rachma, A. R. S. (2019). Pengaruh Harga, Kualitas produk, Dan Lokasi Terhadap Keputusan Pembelian (Studi Kasus Pada Konsumen DRK Cafe Bondowoso). Universitas Islam Malang, 8(11), 1-16.

Viana, R., \& Wartini, S. (2016). Pengaruh Atribut Produk, Iklan dan Kelompok Acuan terhadap Keputusan Perpindahan Merek dari Sepeda Motor Merek Lain ke Merek Honda. Management Analysis Journal, 5(2), 128-135.

Widiawati, \& Raymond. (2020). Journal Of Management, Accounting, Economic
Jurnal Pendidikan Ekonomi Undiksha

Vol. 13 No. 2 (2021)

and Business. Pengaruh Kepemiikan Institusional, Kebijakan Hutang, Keputusan Investasi Dan Profitabilitas Terhadap Nilai Perusahaan, 01, 264274.

Widyasari, S., \& Fifilia, T. (2009). Analisis Pengaruh Produk, Harga, Promosi dan Lokasi terhadap Keputusan Pembelian Rumah (Studi pada Perumahan Graha Estetika Semarang). Tema Indah Manajemen, 6, 159-169. 